\title{
SOCIAL EXCLUSION OF DEMI-MONDAINE AND NYAI IN FRENCH AND INDONESIAN NOVELS
}

\author{
Arifah Arum Candra Hayuningsih \\ University of Amsterdam \\ Email: a.a.c.hayuningsih@uva.nl
}

\begin{abstract}
One of the interesting themes but not widely featured in Indonesian and French literatures in the 19th and 20th centuries is nyai and demi-mondaine. Both have a similar meaning, namely the mistress of a man from the upper-middle class. This study looks at the exclusions that occur in the lives of nyai and demi-mondaine in an Indonesian novel titled Bumi Manusia by Pramoedya Ananta Toer and a French novel titled La Dame aux Camélias by Alexandre Dumas (philosophers). The analysis was carried out using Fairclough's critical discourse analysis approach to examine the exclusion process in the two novels, which describes the realities that occur in society. This study found that the mistresses are excluded primarily through labeling and stereotyping. Despite the exclusion from the discourse of 'honor' in society, the mistresses find their own way of surviving in a society that does not like them.
\end{abstract}

Keywords: demi-mondaine, nyai, novel, exclusion, France, Indonesia

\begin{abstract}
ABSTRAK
Salah satu tema menarik namun tidak banyak ditampilkan dalam karya sastra Indonesia dan Prancis di abad 19 dan 20 adalah kehidupan nyai dan demi-monde. Keduanya memiliki pengertian yang hampir serupa, yakni perempuan simpanan dari seorang laki-laki kelas menengah ke atas. Sikap masyarakat yang cenderung merendahkan mereka dapat dipandang sebagai proses eksklusi. Penelitian ini menelusuri bagaimana ekslusi yang terjadi dalam kehidupan nyai dan courtesan di Indonesia dan Prancis seperti yang ada pada novel Bumi Manusia karya Pramoedya Ananta Toer dan novel La Dame aux Camélias karya Alexandre Dumas (fils). Analisis dilakukan dengan metode analisis wacana kritis dari Fairclough untuk melihat proses eksklusi di kedua novel tersebut, yang merupakan gambaran dari realita yang terjadi di masyarakat. Penelitian ini memperlihatkan bahwa proses eksklusi paling banyak terjadi melalui labelling dan stereotyping. Meski demikian, para perempuan simpanan yang mengalami eksklusi dari wacana 'kehormatan' di masyarakat memiliki cara sendiri untuk bertahan di tengah masyarakat yang tidak menyukai mereka.
\end{abstract}

Keywords: demi-monde; nyai; eksklusi; novel: Prancis; Indonesia

\section{INTRODUCTION}

A mistress's presence is still considered taboo and has to be hidden even though they have been part of the history of civilization. According to Elizabeth Abbot, many things could be the impetus of its presence. Still, one of the major factors is the existence of social class and caste hierarchy that create a matchmaking system between man and woman of the same or even higher social class. This system has created a gap for mistresses to fill. They are often considered more "human" than the wives of nobles. Alexandre Dumas 
(père), a French writer, even says that it takes two or three people to live a marriage life (Abbot, 2013, p. $\mathrm{xx}$ ). Among the various stories about mistresses in the trajectory of cultural history worldwide, two of them appeared in France and Indonesia. Through stories about demi-mondaine in France and nyai in Indonesia, history records how their life has never been free from gossips, insults, and curiosity in public sphere.

Nyai was initially the name for housekeeper in Dutch household but later was used as a term that means a mistress (Taylor, 2009, p. 147). As a mistress, nyai would never be legally married to her Dutch patron. If she had children, the children would automatically be taken by the father. Society hated them because they were considered Dutch 'henchmen'. A demi-mondaine has the same position as a nyai. The term initially referred to a female entertainer with intelligence and skills in the arts or other expertise. Gradually the term was attached to a male aristocratic mistress (Giusti, 2014, p. 16). The similarity between the two is that they are a mistress of a rich man who fulfilled all her needs but would never be legally married to them. Both were considered part of a "system," which was typical in society at that time. Even though society criticized them, ironically, their presence also attracted a great deal of public curiosity.

This study focuses on the life of demi-mondaine in La Dame aux camélias by Alexandre Dumas (fils) and the life of nyai in Bumi Manusia by Pramoedya Ananta Toer. Pramoedya Ananta Toer wrote Bumi Manusia in the 1970s while detained in Buru Island as a political prisoner. The story tells about Minke's life, a Javanese student at HBS (Hogere Burger School), and his love story with Annelise Mellema. Annelise herself was the child of a mixed marriage between a Dutchman named Herman Mellema and a Javanese woman named Sanikem, later referred to as Nyai Ontosoroh. Ontosoroh's life is depicted as wallowing in wealth and power but still inseparable from criticism from the surrounding community, especially in relation to her position as a 'mistress' of a Dutch master ${ }^{1}$.

La Dame aux camélias was written by Alexandre Dumas (fils) in June 1847. It was inspired by the death of Marie Duplessis, one of the most popular demimondaines in France, at the age of 23, which later

1) This is related to the fact that most Dutch who came to the Dutch East Indies already had legal wives in the Netherlands. As a result, a nyai would not be recognized under Dutch law (Taylor, 2009, p. 31). became a quite shocking news and was published in a prominent newspapers during that period (Issartel, 1981, p. 12). Dumas, inspired by the story, adapted it into a love story between a demi-mondaine named Marguerite Gautier and his bourgeois lover, Armand Duval. This novel is gripping and is told from the point of view of the narrator who seems to tell his testimony of the relationship between Gautier and Duval. This novel created controversy because it brought up a story about demi-mondaine's life, which was considered taboo. Although demi-mondaine was an integral part of the life of the French Bourjois in the 18th to 19th centuries (Lintz, 2008, p. 31), it still could not be brought up openly before the public. This novel has been widely adapted into various works of literature, film, and theater. Among them, the most famous one is the theatrical show entitled La Traviata. Not only describing how demi-mondaine and nyai lived in France and the Dutch East Indies, the two novels also portray the exclusion of the two main characters. The issue of exclusion arises because both are considered 'other' or marginal according to the established discourse in society, primarily in relation to their choice to become a mistress.

The duality of the demi-mondaine and nyai's positions-which are needed and discarded-is the focus of the present study. To date, research into $L a$ Dame aux camélias spans many themes. The novel inspired the emergence of realist theater in Europe and America, especially because it shows how society gave moral punishment to women who recognized themselves as mistresses, as Carlson wrote in "Montigny, Laube, Robertson: The Early Realists" (Carlson, 1972). Equally important is Finn's work entitled "Proust and Dumas fils: Odette and La Dame aux camélias" (Finn, 1974), which emphasizes the influence of La Dame aux camélias on the depiction of demi-mondaine characters in French culture at that time. Finn also shows the intertextuality of Marcel Proust's "Un Amour de Swann" with La Dame aux camélias. Lintz in his research on "(Re) Writing a Classic: La Dame aux Camélias and Manon Lescaut" (2008) reveals that the novel is part of the selfreflection of Alexandre Dumas, the philosopher, of his personal life. Even some say that the novel is his autobiography based on his relationship with Marie Duplesis. Coar, through his writing "Sugar and Spice and All Things Nice: The Victorian Woman's All-Consuming Predicament" (2012), explains the 
influence of La Dame aux camélias on the emergence of consumptive female characters in French society in the nineteenth century.

As in the literature review above, the topic of nyai and demi-mondaine has also been widely discussed. Gogwilt, in "The Vanishing Genre of the Nyai Narrative: Reading Genealogies of English and Indonesian Modernism" (2007), underlines that nyai is a product of the Dutch colonial system against its colony. It cannot only be seen as concubinage or cohabitation in the domestic environment, but it could further be described as slavery in another form. Milone conveys a different opinion in his writing on "Indische Culture, and Its Relationship to Urban Life" (1967). According to him, nyai was one of the things that initiated the creation of Indische culture. The nyais were not only Javanese or indigenous women but also Peranakan women (women of Chinese descent born in Indonesia).

One of the critical writings on demi-mondaine is presented in Mogador's autobiographical mode in "Memoirs of a Demi-mondaine in Nineteenthcentury Paris" (2001). In the book, Mogador relates his experience of being courtesan or demi-mondaine in Paris in the 19th century. Seymour in his research on the performance of "Lola Montez in Bavaria", a musical version starring Lola Montez, conveys the same thing about his experiences of being for the sake of -monde of King Ludwig who finally knighted him in 1847.

The study presented in this article intends to fill the gaps in previous studies that have not raised the topic of social exclusion of demi-mondaine and nyai. The exclusion process in society often goes unnoticed although it has been happening for hundreds of years. One can see how the community looks down on the demi-mondaine and nyai as depicted in the two novels, which are the focus of this study. Exclusion from the dominant discourse in society puts them at a disadvantage position that their lives often end tragically. The main research problem in this study is how the exclusion experienced by the demi-mondaine and the nyai in the novels La Dame aux Camélias and Bumi Manusia respectively reflects the societies in France and the Dutch East Indies in the nineteenth and twentieth centuries.

Researches on Bumi Manusia and La Dame aux Camélias have been widely conducted in Indonesia and France. However, the previous studies on those novels are only related to one of the two sociocultural conditions-in Indonesia or in France-in which the respective novels was written. Study on the social exclusion experienced by demi-mondaine and nyai has never been carried out on comparative basis. This study intends to explain how such exclusion of demimondaine and nyai is practiced in society and how they fight against this exclusion.

This study uses Critical Discourse Analysis (CDA) approach developed by Norman Fairclough to see the relationship between the text and the sociocultural conditions where the text is situated. According to Foucault (1990: 102), discourse is a tool used in the interests of power, hegemony, cultural dominance, and science as a tactical element to influence people's mindsets and is bound by certain classes, whereas according to Fairclough (1992: 63-64), the discourse is a form of a person's actions in using language as a means of representation when seeing reality. Fairclough develops a discourse analysis model that includes contributions such as textuality and viewing closed spaces for the larger context of society. In terms of social change, this model is intended to incorporate discourse analysis based on linguistics. The discourse itself refers to using language as a social practice with broader implications than individual activities or to reflect on something. The focus of the CDA analysis is on how language carries specific ideological values in it. This study uses Norman Fairclough's theory of sociocultural practice, which assumes that the social context outside the media affects how discourse appears in the media (Fairclough, 1992, p. 73). In this context, the relationship between text and social practice is mediated by discursive practice. Also, this study use the concept of intertextuality as part of Norman Fairclough's CDA approach. Intertextuality here refers to the influence of history on the narrative and vice versa.

\section{FINDINGS AND DISCUSSION Demi-Mondaine in France in the Nineteenth Century}

By the second half of the nineteenth century, the demi-mondaine existed as a myth in French fiction that brought together sexuality and political decline in France, as in Emile Zola's novel Nana that was published in 1880. Works of French fiction containing this subject were written to replace the romantic stories featuring a weak woman with a golden heart, as Victor Hugo 
explained in Marion de Lorme in 1831. Dumas's semiessay published in 1834 was an apparent reference to female entertainers' classification in France. The book Filles, lorettes et courtisanes divides these female entertainers into three classes related to the social ranks in the mid-1800s France: fille represents the lower class, lorette is in the middle/bourgeois class, and courtesan, often referred to as demi-mondaine, are in the upper/aristocratic class (Dumas, 2000, p. 22). Still, according to him, filles were women who roam the streets and hid behind Paris' dark alleyways. They were frightening because they could bring diseases and threaten social stability. The existence of lorette is often confused with grisette although the two are different. Grisette represents a passive attitude full of tenderness, whereas lorette represents an aggressive attitude and a desire to change. Lucette Cyzba further explains that the emergence of lorette is related to the rise of the bourgeoisie during the July Monarchy and the Second Empire. Lorette used sex as a way to make money and make herself financially secure. Therefore, they could also have a more decent place to live than filles. While many filles lived in Quartier Latin, lorette lived in the elite Nouvelle-Athènes area (Cyzba, 1984).

In his introduction to La dame aux camelias, Dumas fils said that the number of demi-mondaine had become too large and had grown into a separate class demanding more power. According to him, society should also watch out for demi-mondaine's presence because it would trigger competition with respectable women, which could plunge decent women into the same valley of contempt as comfort women (Dumas fils, 1890, p. 27). Marcel Le Clère, in his book Dictionnaire du Second Empire, explains that the terminology of demi-mondaine is used to describe women in the Second Empire period who desperately imitated the aristocratic lifestyle. They looked like aristocrats, living in luxury supported by the nouveaux riches and competing to show their wealth and hegemonic power. However, even though they looked like aristocrats, they belonged to the classless people, considering that they did not want to be in the lower class, but at the same time they were not accepted by the class above them (Le Clère, 1995, p. 414).

Dumas fils's work on the Second Empire's demi-mondaine story of Marguerite, complemented his previous semi-essay work. In his novel, Dumas fils does not place Marguerite as an antagonist.
Readers are instead invited to explore the dark sides of demi-mondaine's life although at the beginning of the story Marguerite can evoke the imagination of a glamorous life through parties and glamorous events that she enjoys. Marguerite is depicted as a romantic protagonist full of sadness and suffering against the backdrop of the romantic tradition of protagonists with their joyful life. Dumas describes the demimondaine world as the antithesis of bourgeois life, which tends to be rigid and confined in all forms of ethics and social prohibitions. We can see it in the description of Marguerite's life which is very luxurious and seems to exist in another world that is not hindered by all social regulations (Dumas fils, 1975, p. 15).

It is also normal for a mistress like Marguerite to have several lovers and patrons simultaneously. Their presence is necessary to finance the luxurious lifestyle of the mistress, as told by Prudence, Marguerite's chaperone.

"How do you suppose the kept women in Paris could live in the style they do, if they had not three or four lovers at once? No single fortune, however large, could suffice for the expenses of a woman like Marguerite. A fortune of five hundred thousand francs a year is, in France, an enormous fortune; well, my dear friend, five hundred thousand francs a year would still be too little, and for this reason: a man with such an income has a large house, horses, servants, carriages; he shoots, has friends, often he is married, he has children, he races, gambles, travels, and what not." (Dumas fils, 1975, p. 143)

Marguerite captivates her admirers and lovers with her beauty and a combination of warm, open, carefree, and melancholic attitudes. As an entertainer with a class of her own, she knows precisely when to warm up the room when the conversation gets too severe. She also understands each of his patrons' personalities and knows how to dress and act the way they want her to. It gives the illusion that they were the only man in Marguerite's heart. For example, to prevent Armand from being jealous of the Duke, Marguerite wears a unique, sexy, and attractive dress so that Armand would forget about his jealousy (Dumas fils, 1975, p. 127)

Dumas also portrays how consumptive 
Marguerite's lifestyle is, which Armand, her admirer, understands very well. Even though he realizes that his relationship with Marguerite would put him in debt, Armand does not care. Instead he floods his mistress with luxurious gifts. The relationship between Marguerite and Armand is also interesting to observe in terms of class opposition. Marguerite, with her position as demi-mondaine, is explicitly considered non-existent by the public and the aristocracy, unlike Armand, whose position belongs to a respected class. Even so, Armand's position, which should be far above Marguerite, is reversed when it comes to wealth. Marguerite is richer than Armand because she receives 10,000 francs per year from her patron, The Duke. However, beneath her confident attitude lurks an inferiority complex because she doesn't deserve to be in the upper class. She realizes that she could never be accepted in the world of the bourgeoisie and the nobility. This situation is clearly stated when Marguerite rejects Armand's love because they belong to different social classes (Dumas fils, 1975, p. 169).

Even after she gets into a relationship with Armand, she still couldn't escape the feeling of inferiority and unworthiness to be together with her noble lover. We can see it when she consciously acknowledges her 'banished' status from society. Armand always reassures her heart by saying that although she is only an ordinary girl (fille) and at the same time a demi-mondaine, she is a noble fille (Dumas fils, 1975, p. 235).

Marguerite's tragic death closes her sad story but becomes the opening door for noblewomen's curiosity about the famous demi-mondaine's life. They flock to her apartment to satisfy their jealousy as well as to take a look at the demi-mondaine world that they would never be able to enter without tarnishing their reputation as aristocrats.

"There were all the celebrities of the most elegant impropriety, furtively examined by certain great ladies who had again seized the opportunity of the sale in order to be able to see, close at hand, women whom they might never have another occasion of meeting, and whom they envied perhaps in secret for their easy pleasures. .. I watched the faces of the auctioneers, noticing how they beamed with delight whenever anything reached a price beyond their expectations. Honest creatures, who had speculated upon this woman's prostitution" (Dumas fils, 1975, pp. 18-19)

Even after Marguerite's death, when all the luxury items in her possession are auctioned off, it is made apparent that the demi-mondaine is only judged by her appearance and possessions. The public only remembers her as an immoral object rather than as a human being.

\section{Nyai in the Dutch East Indies in the Twentieth Century}

Nyai was initially a term for a Dutch housekeeper but later used as a nickname for a mistress. In the Dutch language itself, the term nyai has several equivalent words: bijzit, huishoudster, and menagerie. However, all three do not have the same meaning for nyai. Bijzit means mistress, while huishoudster is more accurately understood as a term for maid and menagerie is a term for housewife (Hellwig, 2001, p. 176). We can see here that the word nyai has undergone a shift in meaning, which made a nyai associated with lewd acts and was no better than just a maid for the Dutch master's household.

The colonial community supported the presence of nyai for several reasons. First, it could prevent the spread of sexually transmitted diseases such as syphilis, which often occurred among soldiers who frequented prostitutes (Stoler, 1989, p. 367). Second, nyai could play housekeeper role who supported Dutch men's 'productivity' in the colony. Third, presenting a nyai as a shadow wife means significant savings compared to bringing in a wife and children from the Netherlands. Fourth, if later there were children born from the relationship with nyai, the Dutchmen did not need to bring them back to the Netherlands (Chivas-Baron, 1929, p. 103).

In the nineteenth century, nyai was a beautiful mistress who lived a lewd life (Ibid., 22)

"She was just a nyai did not know legal marriage, gave birth to illegitimate children, a kind of woman with a low level of morality, sold her honor for a happy and luxurious life." (Toer, 1980, p. 22)

Bumi Manusia shows the stereotype of nyai in society, the exclusion experienced by Ontosoroh from the society (indigenous and Dutch), and how she struggles to uphold her dignity, not only as a nyai but also as a mother of Indo-European children. 
This story of nyai Ontosoroh begins when Sanikem is sold by his father, Sastrotomo, to Herman Mellema for twenty-five guilders with a promise of two years of apprenticeship for Sastrotomo before he is later appointed as the factory's paymaster. Sanikem then changes her name to Nyai Ontosoroh after officially becoming the mistress of Herman Mellema. Gradually, she develops a new behavior because Mellema educates her to be a decent life partner for a European man. Mellema's teachings range from simple ones such as brushing teeth and bathing with soap (Toer, 1980, pp. 88-90) and reading and writing in Malay and Dutch, to learning about agriculture, commercial and legal matters (Ibid., 78). Nyai Ontosoroh is described as being slightly luckier than the other nyai. Mellema as the 'master' who is in charge of her life, not only considers Ontosoroh as a housekeeper but also as a life partner. At the height of Herman Mellema's trust in Ontosoroh, she is even entrusted with all the responsibilities of managing the Boerderij Buitenzorg company (Ibid., 25,92,94). Since then Ontosoroh has another name, which is Nyai Buitenzorg.

Pramoedya Ananta Toer creates an irony in the story by showing the dark side of Ontosoroh's life. Although Ontosoroh is said to have been considered equal, even more so than European women in the eyes of Herman Mellema, when faced with the colonial social and legal system, she is a nobody. She is still just a mistress who is no more valuable than a housekeeper. The problem arises when her children, Robert and Annelies, could not be legally recognized as the children of Herman Mellema with her. They are only recognized as Herman Mellema's children.

According to Cribb and Cahin, marriages between European men and Indonesian women in colonial times could not be recognized by law, even if the woman had been baptized and embraced Christianity. As a result, mestizo children born of such relationships were also not recognized by law (Cribb \& Cahin, 2004, p. 260). Furthermore, in his book on social life in Batavia, Jean Gelman Taylor discusses the ambivalence of Indo-European children born in the Dutch East Indies. They automatically inherited European citizenship from their father, but other Europeans still did not recognize their status. However, they could get full legal recognition as long as they met the following requirements: be baptized as a Christian with a Dutch name, attend a Dutch school with a Dutch education system, dress and behave like a Dutch person, and live in a European household (Taylor, 2009, p. 156).

The above matter further clarifies another problem of the presence of nyai in the colonial society of the Dutch East Indies, namely the recognition of Indo-European children. In the story of Bumi Manusia, the concept of recognition is like a circle that has no end to break. Robert and Annelies Mellema were born and raised in a European household, though nurtured by a nyai. They are educated in European schools and can speak and behave in a European way. However, they have not been baptized in a Christian church because of the lack of marital status between Ontosoroh and Herman Mellema.

"You and your brother are still considered illegitimate children; you are only recognized as children of Mr. Mellema and have the right to use his name. With the intervention of the court of law, it did not recognize your brother and you as my children. You are not my children anymore, even though it was Mama who gave birth to you. Since that decision by the court, you are, by law, the children of Mr. Mellema.... The story goes on, Ann. The Master (Mellema) wants you both to be baptized. I'm not taking you to church. You go home early. The priest refuses your baptism." (Toer, 1980, p. 98)

Until the end of the story, they are the children of Herman Mellema in the eyes of the law but are not considered the children of Ontosoroh. Robert and Annelies Mellema have a legal father but lose their mother only because of her position as a nyai. because of this situation, Ontosoroh realizes that in front of the society, she would be nyai for the rest of her life despite having Mellema as her 'husband'.

\section{Exclusion: Natural Process or Artificial?}

The discourse on exclusion and inclusion begins with a discussion presented by Foucault on the relationship between power and knowledge. Certain discourses will produce certain truths and knowledge with a powerful effect of one party over another. Even though there are many discourses in society, one discourse will become dominant and makes other discourses marginalized/excluded because the ruling party chooses and supports that particular discourse (Foucault, 1980). In this case, demi-mondaine and nyai 
are considered entities that must be 'hidden' and 'defeated' by the dominant discourse in society.

The demi-mondaine world is a kind of 'paradise' where its members can get pleasure without being bound by consequences and social rules for the aristocrats. For Dumas fils, the triangular relationship between the nouveau riche, demi-mondaine and aristocrats illustrates in detail the pattern of relations between social mobility and prostitution (Dumas fils, 1975, p. 513). Through his work, he also wants to show that Marguerite's lifestyle does not come as something that is free of consequences. There is a high price to be paid by Marguerite. The price is tuberculosis she has to suffer which leads to her tragic death. Mistresses like Marguerite are also described as having no one by their side to trust. Everyone wants to take advantage of her, even to the point of death (Dumas fils, 1975, p. 171).

The exclusion process is shown by the male author through the initial narration or the selection of a male narrator. Although Dumas fils wants to put himself in a neutral position, his effort does not go well because, in the end, the story of Marguerite, which Dumas fils describs in a backward plot, seems to be just a flashback to the demi-mondaine's 'sin' that makes Marguerite's death natural, as said at the beginning of the novel. The reader is informed that the demi-mondaine whose story is about to be told is dead. Any stories about her sinful life will not affect society.

"I content myself with narrating, and I beg the reader to assure himself of the truth of a story in which all the characters, with the exception of the heroine, are still alive... This one was dead, so the most virtuous of women could enter even her bedroom. Death had purified the air of this abode of splendid foulness, and if more excuse were needed, they had the excuse that they had merely come to a sale, they knew not whose." (Dumas fils, 1975, pp. 4-5)

Until the end of her life, the society where she lives rejects Marguerite, as told by Marguerite's cemetery worker below:

"Poor lady, she's dead now; there's no more of her left than of them that no one has a word to say against. We water them every day. Well, when the relatives of the folk that are buried beside her found out the sort of person she was, what do you think they said? That they would try to keep her out from here, and that there ought to be a piece of ground somewhere apart for these sort of women, like there is for the poor." (Dumas fils, 1975, p. 45)

For Ontosoroh, her life story is like a scenario that the screenwriter, namely patriarchal power, has outlined. It starts when she is sold by his father, Sastrotomo, to Herman Mellema. Since then, she has experienced various forms of exclusion from society. Among them is labelling her as an immoral figure because she wants to marry a Dutchman without a legal recognition (Ibid., 50-51). She is also considered a temptress (Ibid., 134, 138). Furthermore, nyai is also labelled as 'destroyer' of the household of a Dutchman and his legal wife in the Netherlands, as alleged by Maurits Mellema, the legitimate son of Herman Mellema

"You (Mellema) are legally my mother's husband. But it is You who has taken a domestic woman as an escort, not for a day or two, for decades! Day and night. Without a legal marriage. You have caused the birth of two illegitimate children!" (Toer, 1980, p. 104)

Nyais are also excluded from the established discourse in society because of the stereotype that they are stupid and illiterate, and their sole function is a servant of their master's lust (Ibid., 22,23,74). Any form of exclusion, of course, leads to inferiority and shame. Ontosoroh also admits her guilt when she first becomes a nyai. She does not want to leave the house for a year because she is afraid of what people think of her, as she explains to her daughter in the quotation below:

"Ann, for a year, I lived in the house of Lord Herman Mellema. Never go out, never take a walk or meet anyone. What's the point? I am ashamed of the world, especially on acquaintances, neighbors. ... There can be no witnesses to my life as a nyai. There can be no news about me: a despicable woman without price." (Toer, 1980, pp. 91-92)

The difference between the exclusion in Bumi Manusia and that in La Dame aux Camélias is the presence of children. In La Dame aux camelias, Marguerite is not told to have children from her relationship with Armand until the end of her life. On the contrary, Ontosoroh has two children from 
Mellema, namely Robert and Annelies. These children are considered illegitimate children, so they cannot be legally recognized. To get legal recognition, they must first be baptized in a Christian way, but the Christian church does not want to provide baptism for children born out of legal marriage. Mellema is still bound to his legal marriage in the Netherlands so he could not marry Ontosoroh. As a result, Annelies and Robert are not recognized as Ontosoroh and Herman Mellema's children. They are only considered as children of Herman Mellema (Ibid., 79, 97-98).

\section{Defend or Fight?}

We can liken the relationship between demimondaine and aristocrats to the relationship between commodities and owners of capital. If demi-mondaine were able to attract nobles as customers, its 'sales value' would increase. To the nobility themselves, their ability to 'possess' demi-mondaine demonstrated their financial strength. Therefore, the relationship between the two can be said to distinguish themselves from others around them.

At the end of the story, as her death draws nearer, the lonely Marguerite has no regrets about leaving Armand at the request of Armand's father (Dumas fils, 1975, p. 218). She does not protest her tragic life and destiny. Instead, she is proud of her sacrifice for Armand's happiness (Ibid., 236). Marguerite's willingness to give up for Armand's happiness shows how strong the influence of the dominant class isthe aristocrats-on the lives of demi-mondaines as a group of people that are deliberately removed from the dominant discourse. Marguerite not only accepts her fate related to her 'exclusion', but also gives the bourgeoisie an opportunity to control her life by fulfilling Armand's father's wish to leave Armand for the sake of his family's good name.

In addition to opposing class differences, Dumas fils also shows how dominant women are in the relationship between Armand and Marguerite as a representation of demi-mondaine's relationship with her master. In that era, in a society which requires women to surrender themselves to men completely, Armand states that he is a slave of Marguerite, which makes her capable of doing whatever she wants to do to Armand (Dumas fils, 1975, p. 268). Marguerite is also the one who decides when and where her lovers, including Armand, may visit her (Ibid., 93). Furthermore, Marguerite also emphasizes that she has many lovers so that Armand should not be jealous and or have the desire to monopolize her. Armand is also described as accepting this treatment with full awareness in the name of his great love for Marguerite (Ibid., 109). It is interesting to observe that even though Marguerite is removed from the dominant discourse, she is able to dominate those who get rid of her, even though she could only do that through Armand Duval.

In the story of Bumi Manusia, Ontosoroh is not silent when she is oppressed. At first, Ontosoroh shows her resistance in a cooperative and non-frontal manner. She absorbs all the knowledge taught by Mellema so that later she can be independent and no longer depend on him. She is ready when Mellema returns to the Netherlands and leaves her with Robert and Annelies (Ibid., 92). Later, she reverses the relationship pattern from the nyai's dependence on the master to the master's dependence on the nyai (Ibid., 93). Ontosoroh begin to take control of the Mellema company. Gradually, people begin to associate Boerderij Buitenzorg with Ontosoroh, instead of with Mellema (Ibid., 97). She is responsible for the entire company, from correspondence to finance. At one point, Ontosoroh even feels that she is already on a par with other European women, especially with the fact that not all European women have the power to manage a company as big as hers (Ibid., 96).

More interestingly, Ontosoroh begins to show complete 'mastery' of Mellema when he becomes depressed after the visit of Maurits Mellema, the son of his legal marriage with Amelia Mellema. His arrival shakes Herman Mellema's feelings and makes him depressed. However, Ontosoroh does not remain silent when Herman Mellema acts like a madman. For her, the company and their children must be saved first because if the court finds out that Herman Mellema has depression and mental disorders, the entire company and his family will be placed under the supervision of a caretaker appointed by the court (Ibid., 79). To protect the company and her family, Ontosoroh immediately takes control of Boerderij Buitenzorg with the help of Darsam as her right-hand man.

The conflict in Bumi Manusia reaches its climax when Herman Mellema is found dead due to poisoning of certain substances that may have come from the alcohol he consumes during his depression. He is found dead in Ah Tjong's brothel by Darsam, Minke, 
Ontorosoh, and Annelies. The incident shocks the public and is then reported massively in the local newspapers. The trial of Ah Tjong as the accused is also carried out by presenting witnesses, including Ontosoroh and Minke.

The trial is supposed to be held to find out who is responsible for Herman Mellema's death, but then it turns into a morality trial. Nyai Ontosoroh is publicly mentioned as the concubine of the late Mellema. Ontosoroh certainly does not take the ridicule thrown at her by the judges and prosecutors quietly. To defend herself she shows a frontal resistance to the exclusion of and stereotypes against her as a nyai.

Nyai Ontosoroh uses the trial as a medium to file a lawsuit against the European masters who, according to her, are the party most responsible for her concubine or nyai status (Toer, 1980, p. 323). Her anger explodes when the judge brings up Minke and Annelies' love story, which is inappropriate because Minke is a native while Annelies is an Indo-European. For Ontosoroh, this issue is irrelevant to the trial case (Ibid., 322).

Ontosoroh does not show resistance when she is insulted and considered only a concubine by the panel of judges, but when her child is mentioned, her anger explodes. Pressured by the situation, she discloses the facts about Mellema's company, which would not develop without her help (Ibid., 382). She also tells Minke that he has to fight. Otherwise, the company and the rights as Annelies's legal guardian would be handed over to Maurits Mellema as the legal son of Herman Mellema. For her, Annelies' honor and dignity must be prioritized above herself (Ibid., 325).

Ontosoroh's self-defense at the trial receives supports from many people, especially from those who resent the law that brings injustice to the Indigenous and Indo-European groups. One of them is Kommer, a journalist who writes that the actions of the prosecutors and judges are an insult to all Indo-European groups who come from concubines. Even Kommer also evaluates that the court process that tries Nyai Ontosoroh's morals is no better than Wiroguno's trial of Pronocitro (Ibid., 325)

\section{CONCLUSION}

Both Nyai and demi-mondaine experience exclusion from the discourse of 'honor' that exists in society. This is represented in the descriptions that people make about them, which mostly place them as women who have no honor and dignity. However, people are also curious about their lives, especially regarding their lifestyle and wealth. Ontosoroh and Marguerite are not aware of this exclusion. At one point, they feel proud of their status as mistresses.

There is a paradox in the pattern of exclusion of nyai and demi-mondaine in Bumi Manusia and La Dame aux Camélias respectively. Both exclusions are based on discourses on morality, honor, and dignity of women. We can say that the French and Dutch East Indies societies in the past still perceives that woman who were openly the mistress of a man, let alone having children, were dishonorable women. Society did not see how smart and rich the demi-mondaine and nyai were. Ironically, society does not blame and look down on men who are the 'masters' of a nyai, as if their behavior is natural. In other words, it is better to be a rich man who can have mistresses than to be a rich woman who have lovers.

Social exclusion is expressed through labelling or stereotyping demi-mondaine and nyai as immoral, uneducated, money-hungry, and women who knows nothing but how to attract men using their beauty. Although Marguerite and Ontosoroh are intelligent, wealthy, and independent women, society ignores their positive qualities only because of their position as mistresses. They do not just stay silent with all the exclusions they experience. They defend themselves and fight in almost the same but different ways. What they have in common is that they fight against this exclusion by creating dependence on themselves. Armand Duval even admits that he is a slave of Marguerite, while Herman Mellema realizes that his company and himself would be doomed without Ontosoroh by his side.

The two novels don't show much of Marguerite and Ontosoroh's strength and survival strategies. This lack of description is not without criticism, as it emphasizes the patriarchal gaze in literary works. Following the publication of Dumas fils' La Dame aux Camélias, many demi-mondaines wrote novels and autobiographies as counter-narratives to Dumas fils' novels. Céleste Mogador's La Sapho (1858) and Liane de Pougy's L'Insaisissable (1898) and Myrrhille or the Mauvaise Part (1899) are the most famous counter-works (1899) to Dumas fils's works. The counter-narrative becomes a research opportunity, particularly for novels in the courtesan sub-genre. 


\section{REFERENCES}

Abbot, E. (2013). Wanita Simpanan: Kontroversi Selingkuhan Tokoh-Tokoh Dunia, dari Orang Suci hingga Politisi, dari Zaman Kuno hingga Era Kini (A. Soemarni, Trans.). Jakarta: PT. Pustaka Alvabet.

Carlson, M. (1972). Montigny, Laube, Robertson: The Early Realists. Educational Theatre Journal, 24(3), 227-236.

Chivas-Baron, C. (1929). La femme française aux colonier. Paris: Larose.

Coar, L. (2012). Sugar and Spice and All Things Nice: The Victorian Woman's All-Consuming Predicament. Victorian Network, 4(1).

Cribb, R., \& Cahin, A. (2004). Historical Dictionary of Indonesia (Second). Lanham, Maryland: Scarecrow Press.

Cyzba, L. (1984). Paris et la Lorette. In Paris au XIXe siècle. Aspect d'un mythe littéraire. Lyon: PUF de Lyon.

Dumas, A. (2000). Filles, lorettes et courtisanes (4th ed.). Paris: Flammarion.

Dumas fils, A. (1890). À Propos de La Dame aux Camélias. Théâtre Complet, 1.

Dumas fils, A. (1975). La Dame aux camélias. Paris: Livre du Poche.

Fairclough, N. (1992). Discourse and Social Change. Cambridge: Polity Press.

Finn, M. R. (1974). Proust and Dumas fils: Odette and La Dame aux camellias. The French Review, 47(3), 528-542.

Foucault, M. (1980). Power/Knowledge. New York: Pantheon.
Giusti, E. L. (2014). The Renaissance Courtesan in Words, Letters and Images. Milano: Edizioni Universitarie di Lettere Economia Diritto.

Gogwilt, C. (2007). The Vanishing Genre of the Nyai Narrative: Reading Genealogies of English and Indonesian Modernism. Comparative Literature Studies, 44(3), 409-443.

Hellwig, T. (2001). Asian Women in the Lives of Dutch Tea Planters: Two Narratives from West Jawa. Indonesia and the Malay World, 29(85), 161-179.

Issartel, C. (1981). Les Dames aux camélias: De l'histoire à la legende. Paris: Chêne-Hachette.

Le Clère, M. (1995). Demi-Mondaines. In Dictionnaire du Second Empire. Paris: Fayard.

Lintz, B. C. (2008). (Re)Writing a Classic: La Dame aux Camélias and Manon Lescaut. Dalhousie French Studies, 83, 25-41.

Milone, P. D. (1967). Indische Culture, and Its Relationship to Urban Life. Comparative Studies in Society and History, 9(4), 407-426.

Mogador, C. (2001). Memoirs of a Courtesan in Nineteenthcentury Paris. Lincoln\&London: University of Nebraska Press.

Stoler, A. L. (1989). Making Empire Respectable: The Politics of Race and Sexual Morality in 20thCentury Colonial Cultures. American Ethnologist, 16(4), 634-660.

Taylor, J. G. (2009). The Social World of Batavia, Europeand and Eurasians in Colonial Indonesia (Second). Wisconsin: The University of Wisconsin Press.

Toer, P. A. (1980). Bumi Manusia. Jakarta: Lentera Dipantara. 